the lactating rat. J Nutr 117:725-731

26. Combs G, Combs SB 1984 The nutritional biochemistry of selenium. Ann Rev Nutr 4:257-280

27. Debski B, Picciano MF, Milner J 1989 Selenium content and GSH-Px of milk from vegetarian and non-vegetarian women? J Nutr 1 19:215-220

28. Mepham TB 1983 Biochemistry of Lactation. Elsevier Science Publishing Co, New York

29. Lockitch G, Jacobson B, Quigley G, Dison P, Pendray M 1989 Selenium deficiency in low birth weight neonates: an unrecognized problem. $J$ Pediatr 114:865-870

30. Smith AM, Picciano MF, Milner JA, Hatch TF 1988 Influence of feeding regimens on selenium concentrations on glutathione peroxidase activities in plasma and erythrocytes of infants. J Trace Elem Exp Med 1:209-216
31. Amin S, Chen SY, Collip PJ, Castro-Magan M, Maddiah JVT, Klein SW 1981 Selenium in premature infants. Nutr Metab 24:331-340

32. Frank L, Groseclose EE 1982 Oxygen toxicity in newborn rats: the adverse effects of undernutrition. J Appl Physiol 53:1248-1255

33. Frank L 1985 Effects of oxygen on the newborn. Fed Proc 44:2328-2334

34. Frank L, Groseclose EE 1984 Preparation for birth into an $\mathrm{O}_{2}$ rich environment: the antioxidant enzymes in the developing rabbit lung. Pediatr Res $18 \cdot 240-244$

35. Frank I, Sosenko I 1987 Development of lung antioxidant enzyme system in late gestation: possible implications for the prematurely born infant. J Pediatr 110:9-14

36. Lawrence RA, Burke RF 1978 Species, tissue, and subcellular distribution of non-Se-dependent glutathione peroxidase activity. J Nutr 108:211-215

\title{
Announcements
}

\section{Call for Abstracts}

The Society for Behavioral Pediatrics will conduct its 8th Annual Scientific Meeting on September 16-17, 1990 at the Westin Hotel in Denver, CO. We invite you to submit abstracts of research papers for consideration for presentation at the scientific sessions. ABSTRACTS MUST BE RECEIVED BY MARCH 1, 1990. For further information and abstract forms, please contact: Ms. Noreen Spota, SBP Business Administrator, 241 East Gravers Lane, Philadelphia, PA 19118, (215) 248-9168.

\section{Special Program in Nutrition for a Healthy Heart Developed for Grade School Children and Their Parents}

The J. David Gladstone Foundation of the University of California, San Francisco, has developed a heart healthy nutrition education curriculum for third grade students and their parents. This curriculum, called the Special Program in Nutrition (SPIN), consists of two manuals and a cookbook collection of low fat, low cholesterol recipes. The manuals contain an in-service program for teachers, 27 lessons for third grade students, seven lessons for fourth grade students, and a parent's program with ten planned meetings.

The cost of the complete set is $\$ 35.00$; the two-volume curriculum and the cookbook may be purchased separately for $\$ 30.00$ and $\$ 10.00$, respectively. Add $6.5 \%$ California sales tax where applicable. For further information contact: The Gladstone Foundation Laboratories, 2550 23rd Street, P.O. Box 40608, San Francisco, CA 94140, (415) 826-7500.

\section{Third Congress on Trace Elements in Medicine and Biology}

The French Society for Study and Research on Essential Trace Elements will hold its Third Congress on Trace Elements in Medicine and Biology at Les Deux Alpes, France, January 15-18, 1991. For additional information contract: Arlette Alcaraz, Laboratoire de Biochimie C-CHRU de Grenoble, BP 217 X, 38043 Grenoble CEDEX. Telephone: 76.42.81.21, extension 4465 .

\section{ANNUAL MEETINGS}

The American Pediatric Society, The Society for Pediatric Research and The Ambulatory Pediatric Association will meet May 7-11, 1990; Anaheim Hilton \& Towers and Convention Center, Anaheim, CA.

Contact: APS or SPR: Association Headquarters, 2650 Yale Blvd., S.E., Suite 104, Albuquerque, NM 87106, (505) 764-9099 or 0068. APA: Ambulatory Pediatric Association, 6728 Old McLean Village, McLean, VA 22101, (703) 556-9222.

\section{FASEB Summer Conference on Physiology and Pathophysiology of the Splanchnic Circulation}

The FASEB Summer Research Conference, "Physiology andd Pathophysiology of the Splanchnic Circulation," will be held at Copper Mountain, CO on July 22-27, 1990. For further information contact The Federation of American Societies for Experimental Biology, Splanchnic Circulation Conference, 9650 Rockville Pike, Bethesda, MD 20814. 